\title{
Airborne microeukaryote colonists in experimental water containers: diversity, succession, life histories and established food webs
}

\author{
Savvas Genitsaris ${ }^{1}$, Maria Moustaka-Gouni ${ }^{1, *}{ }^{,}$Konstantinos A. Kormas $^{2}$ \\ ${ }^{1}$ Department of Botany, School of Biology, Aristotle University of Thessaloniki, 54124 Thessaloniki, Greece \\ ${ }^{2}$ Department of Ichthyology and Aquatic Environment, School of Agricultural Sciences, University of Thessaly, \\ 38446 Nea Ionia, Magnisia, Greece
}

\begin{abstract}
Airborne freshwater and marine microeukaryotes in the city of Thessaloniki, situated in Thermaikos Bay, Greece, were examined as sources of colonization of experimental water containers during the period autumn 2007 to spring 2008. The microeukaryote composition of the plankton in the nearby aquatic systems (distance $<1 \mathrm{~km}$ ) was also examined. Airborne microeukaryotes were examined by morphology and 18S rRNA gene diversity. A total of 29 species of airborne microeukaryotes were identified, most of them commonly observed in aerobiological studies. Airborne organisms of only 8 taxa were also detected in the nearby aquatic systems. The algae Haematococcus lacustris, a Chlorella-like taxon, and Scenedesmus cf. obliquus, the heterotrophic nanoflagellates (HNF) Bodo sp., Cafeteria minuta and Rynchomonas nasuta, and the ciliate Pattersoniella vitiphila were present in all 3 seasons, indicating capabilities of successful dispersal and colonization under a wide range of meteorological conditions. Rapid colonization of the water containers by the microeukaryotes occurred at the beginning of the experiment, but the rate of colonization quickly stabilized. The initial phase of colonization was dominated by HNF; subsequently, members of the Chlorophyta were the dominant autotrophs. The heterotrophic and autotrophic colonists established similar food webs in all 3 seasons, with $P$. vitiphila being the common top predator.
\end{abstract}

KEY WORDS: Airborne microeukaryotes $\cdot$ Colonization $\cdot$ Diversity $\cdot$ Food web $\cdot$ Haematococcus Pattersoniella Resale or republication not permitted without written consent of the publisher

\section{INTRODUCTION}

The atmosphere is considered to harbour a wide mixture of microorganisms, such as bacteria, protozoa, fungi and microalgae, including phytoplankton (Hamilton \& Lenton 1998). Even though the existence of airborne autotrophic and heterotrophic microbial eukaryotes, and their ecological and economic importance, have long been recognized (see Stetzenbach 2002, Sharma et al. 2007 for reviews of the early literature), many basic aspects of their biology are still poorly understood (with the exception of fungi). Also, the airborne marine microscopic eukaryotes are under-studied, compared to their freshwater counterparts (Hamilton \& Lenton 1998).
Eukaryotic microorganisms are characterized by short generation times, high dispersal capabilities and large population sizes, properties that distinguish them from multicellular organisms (Dolan 2005). These properties are linked to their often ubiquitous dispersal and cosmopolitan distribution (Finlay \& Clarke 1999, Finlay 2002). However, there are also biogeographical patterns displayed by certain microorganisms (Hughes Martiny et al. 2006). The successful dispersion of freshwater and marine eukaryotic microorganisms is promoted by their resistant life stages - for example, the vegetative and resting stages of phytoplankton (Chrisostomou et al. 2009) and the cysts of protozoa (Corliss \& Esser 1974)- 
which facilitate their transport through air and by animal vectors. It also seems that the observed biogeography of aquatic microeukaryotes is influenced by the method of study: species identified solely by morphology seem to be widely distributed, but whether such species come from the same genetic populations remains debatable (Dolan 2005). Thus, there is a demand for combining information on the distribution of microeukaryotes based on morphology and phylogeny with information on life cycles and colonization potential in order to unravel biogeographical trends.

The majority of airborne algae belong to the Chlorophyta (Schlichting 1964, Lopez-Bautista et al. 2007, see also review by Sharma et al. 2007). This group of autotrophs forms the bulk of the community of aeroalgae in most biogeographic regions, as proposed by Roy-Ocotla \& Carrera (1993). Even deserts are found to be hotspots for chlorophyte biodiversity (Lewis \& Lewis 2005). The few available studies that focus on airborne protozoa from different habitats and regions reveal some common taxa in their lists (Schlichting 1964, Schlichting 1969, Smith 1973, Rivera et al. 1992, Rogerson \& Detwiler 1999) but they do not provide insight on the fate and the interactions of these airborne microorganisms.

Chrisostomou et al. (2009), in a study of air-dispersed phytoplankton in a river-reservoir system, found that algal colonists in experimental water containers were from the local phytoplankton community, including cosmopolitan algae common in most biogeographic regions; their study focused on the colonization potential of freshwater algae and not on heterotrophic microeukaryotes. Dickerson \& Robinson $(1984,1985)$ studied the colonization process, in beakers used as island analogues, by species of microeukaryotes, including heterotrophs, and discovered a more or less stochastic colonization process; however, their studies did not focus on biotic interactions among the colonists (e.g. trophic interactions).

We explored airborne freshwater and marine microeukaryotes in an urban environment (the city of Thessaloniki, situated in Thermaikos Bay, Greece) as a source of organisms for the colonization of experimental water containers. First, we examined the composition of the algae and protozoa in the nearby natural aquatic systems (marine and freshwater) and in the city air during the period autumn 2007 to spring 2008. Next, we investigated the diversity and succession of the airborne microeukaryote colonists - dispersed by air and animal vectors - in the experimental water containers. Finally, we examined the dynamics of the microeukaryote colonists in established food webs, including life cycles of the 2 dominant species in the food webs.

\section{MATERIALS AND METHODS}

Experimental setting. The city of Thessaloniki $\left(40^{\circ} 37^{\prime} \mathrm{N}, 22^{\circ} 57^{\prime} \mathrm{E}\right)$, built at the northernmost tip of Thermaikos Bay (North Mediterranean Sea), is a densely populated and industrialized city. It is reported to have high ambient concentrations of airborne particles that contain elements present as $\mathrm{NaCl}, \mathrm{K}_{2} \mathrm{O}, \mathrm{NiO}$, $\mathrm{Cr}_{2} \mathrm{O}_{3}, \mathrm{MnO}_{2}, \mathrm{Fe}_{2} \mathrm{O}_{3}, \mathrm{PbO}, \mathrm{Cu}_{2} \mathrm{O}, \mathrm{ZnO}, \mathrm{Sb}_{4} \mathrm{O}_{6}, \mathrm{CdO}$, $\mathrm{V}_{2} \mathrm{O}_{5}, \mathrm{As}_{2} \mathrm{O}_{5}$ and $\mathrm{Co}_{3} \mathrm{O}_{4}$ at levels greater than the proposed daily and annual limits according to Council Directive 83/399/ECC (Voutsa et al. 2002). The atmospheric pollen concentration is doubling every decade, with possible consequences for human health (Damialis et al. 2007). Furthermore, allergenic fungal spores have been commonly found (Gioulekas et al. 2004). The experimental site was set on the rooftop of the Biology Department (at a height of ca. $50 \mathrm{~m}$ ) in the Aristotle University of Thessaloniki; the university is located in the centre of the city, and the experimental site is in an open area of the campus surrounded by growing vegetation and with a small permanent water pool $\left(600 \mathrm{~m}^{2}\right)$ nearby. Meteorological data for the periods of the study were provided (Table S1 in the supplement at www.int-res.com/articles/suppl/a062 p139_supp.pdf; T. Mavrommatis, Department of Geology, Aristotle University of Thessaloniki, pers. comm.). Field and experimental procedures. Marine and freshwater plankton samples from Thermaikos Bay and from the university pool, respectively, were collected weekly from surface water in accordance with Mihalatou \& Moustaka-Gouni (2002) during the period October 2007 to April 2008.

Airborne particles were recovered during the same period using an air sampler which collected air at a rate of $161 \mathrm{~min}^{-1}$. The air was drawn into a conical flask containing $300 \mathrm{ml}$ of sterile distilled water, and airborne particles were trapped and collected in the water. From this water, fresh and Lugol-preserved subsamples were taken for microscopic analysis. Samples were taken twice a week, with each air sample being $3 \mathrm{~m}^{3}$.

At the same time as the collection of airborne particles, passively dispersed airborne microorganisms were collected in tap water containers (length: ca. $50 \mathrm{~cm}$, width: ca. $30 \mathrm{~cm}$, volume: ca. 10 l) placed on the same rooftop. Prior to the experiments involving collection of airborne microorganisms, in order to determine the appropriate duration of the experimental periods and the number of replicate treatments, preliminary experiments were performed in the summer of 2007. For the main experiment, 3 experimental periods (autumn, winter, spring) were set up, each lasting $6 \mathrm{wk}$ within the period from October 2007 to April 2008: from 23 October to 4 December 2007 in autumn, from 15 January to 26 February 2008 in win- 
ter, and from 5 March to 16 April 2008 in spring. In each experimental period, 2 sets of 5 water containers filled with water were placed on the rooftop. One set of containers was filled with tap water. Although the tap water was not sterilized, microscopic examination of tap water was carried out and no microeukaryote cells were ever detected. We filled the other set of containers with sterile, aged-ca. 1 yr-seawater (consecutively filtered through filters of $1.2 \mu \mathrm{m}$ and $0.2 \mu \mathrm{m}$ pore size and autoclaved). Each set of containers included 2 replicates covered with $1 \mathrm{~mm}$ mesh (covered containers), in order to avoid animal vectors, and 2 completely uncovered replicates (open containers), together with a control container covered with a plastic sheet. In total, 8 collection containers and 2 controls were set up for each experimental period. Samples of ca. 0.51 from all experimental containers, including the control containers, were collected at the end of each week and fresh and Lugol-preserved subsamples were taken for microscopic analysis. During sampling for the airborne particles with the air sampler, all containers were temporarily covered in order to prevent cross-contamination.

Laboratory analyses. Fresh subsamples for microscopic analysis were examined within $3 \mathrm{~h}$ of collection. Fresh and Lugol-preserved subsamples were examined in sedimentation chambers using an inverted microscope (Nikon Eclipse TE 2000-S) with phase contrast. Airborne and plankton microeukaryotesexcluding fungi-were identified using taxonomic keys. Microeukaryote counts (cells, colonies or filaments) were performed for the samples taken from the experimental water containers using the inverted microscope method (Utermöhl 1958). At least 400 ind. in total, and 100 ind. of the most abundant taxa, were counted per sample in sedimentation chambers of 100 , $50,25,10,5$ and $2 \mathrm{ml}$, depending on the density of the microeukaryotes in the samples. The dimensions (length and width) of ca. 30 ind. (cells, colonies or filaments) of each dominant taxon were measured using a digital microscope camera (Nikon DS-L1).

Samples for the identification of microscopic eukaryotes by the 18S rDNA method were collected from the water containers in the final week of each experimental period. They were brought to the laboratory in 0.51 sterile plastic bottles within $1 \mathrm{~h}$ of collection, $100 \mathrm{ml}$ of water were filtered through membrane filters of $0.2 \mu \mathrm{m}$ pore size (Whatman) and stored immediately at $-20^{\circ} \mathrm{C}$ until further analysis. DNA was extracted using the UltraClean Soil DNA isolation kit (MoBio Laboratories) according to the manufacturer's protocol, after slicing the filters with a sterile scalpel. For the 18S rRNA gene amplification, the primers EukA (5'-AAC CTG GTT GAT CCT GCC AGT-3') (Medlin et al. 1988) and Euk1633rE (5'-GGG CGG TGT GTA CAA RGR G-3')
(Dawson \& Pace 2002) were used. PCR was carried out under the conditions described in Genitsaris et al. (2009). Each PCR was repeated with different cycle numbers (between 16 and 34). The lowest number of cycles (22 cycles) that gave a positive signal was then used for cloning and sequencing in order to eliminate some of the major intrinsic limitations of PCR, such as the formation of artifactual PCR products (von Wintzingerode et al. 1997, Spiegelman et al. 2005) and to avoid differential representation of 18S rRNA genes with low and high copy numbers. PCR products were then visualized, purified, cloned and sequenced following the methods used by Genitsaris et al. (2009). For each clone library, a maximum of 23 clones containing an insert of ca. $1600 \mathrm{bp}$ were examined.

For the detection of closest relatives, all sequences were compared with the BLAST function (www.ncbi. nlm.nih.gov/BLAST/). Sequence data were compiled using MEGA4 software (Kumar et al. 2008) and aligned with sequences obtained from GenBank (www.ncbi.nlm.nih.gov) databases, using the ClustalX aligning utility. Phylogenetic analyses were performed using minimum evolution and parsimony methods implemented in MEGA4 (Kumar et al. 2008). Heuristic searches under minimum evolution criteria used 1000 random-addition replicates per data set, each followed by tree bisection-reconnection topological rearrangements. The topology of the tree was based on neighbour-joining according to Jukes-Cantor. Bootstrapping under parsimony criteria was performed with 1000 replicates. Sequences of unique phylotypes found in this study have GenBank accession numbers HM030909 to HM030919. Library clone coverage was calculated by the formula $\left[1-\left(n_{1} / N\right)\right]\left(\right.$ Good 1953), where $n_{1}$ is the number of operational taxonomic units (OTU) represented by only 1 clone and $N$ is the total number of the clones examined in each library.

Characterization of microeukaryote colonists. The characterization of the airborne colonists was possible only for the colonists in containers filled with tap water, because of the very low diversity and density of the microeukaryotes in the containers with seawater. The airborne taxa were assigned to categories, according to the results from microscopic analysis, on the basis of frequency of appearance, abundance, generation time and individual size (cell, colony or filament). Frequency categories were based on the number of samples in which the airborne taxa were found. The resulting categories were: taxa present with low frequency (L) (found in 1 to 24 of the total of 72 samples in all 3 seasons); medium frequency (M) (found in 25 to 48 of the 72 samples); and high frequency $(\mathrm{H})$ (found in 49 to 72 of the 72 samples). Using the maximal dimension of individuals, 3 size categories were defined: small-sized 
(SS) taxa $(<35 \mu \mathrm{m})$, medium-sized (MS) taxa (35 to $100 \mu \mathrm{m})$ and large-sized (LS) taxa $(>100 \mu \mathrm{m})$. Abundance categories were based on the maximum abundance of each taxon in the water containers during the whole study period resulting in different abundance categories for the SS, MS and LS taxa: (1) for SS microorganisms, taxa of low (L) $\left(<1000\right.$ cells $\left.\mathrm{ml}^{-1}\right)$, moderate (M) (1000 to 10000 cells $\mathrm{ml}^{-1}$ ) and high abundance (H) (>10 000 cells ml $\left.^{-1}\right)$, (2) for MS microorganisms, taxa of low (L) $\left(<100\right.$ cells ml$\left.^{-1}\right)$, moderate (M) (100 to 1000 cells ml ${ }^{-1}$ ) and high abundance $(H)(>1000$ cells $\mathrm{ml}^{-1}$ ), and (3) for LS microorganisms, taxa of low (L) $\left(<10\right.$ cells ml$\left.^{-1}\right)$, moderate (M) (10 to 100 cells ml $\left.^{-1}\right)$

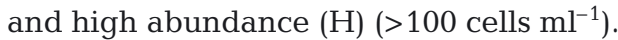

Population net growth rate $(r)$ was determined from changes in the population abundance between 2 consecutive samples $\left(B_{i}, B_{i-1}\right)$ collected at times $t_{i}$ and $t_{i-1}$ (wk) divided by 7 in order to calculate the value per day according to the equation:

$$
r=\left(\frac{\ln B_{i}-\ln B_{i-1}}{t_{i}-t_{i-1}}\right) / 7 \quad\left[\mathrm{~d}^{-1}\right]
$$

Generation time was calculated as 1/r. Accordingly, airborne taxa were divided into categories: taxa with a short generation time (SGT) $(<1 \mathrm{~d})$, taxa with a moderate generation time (MGT) (1 to 2 d) and taxa with a long generation time (LGT) (>2 d).

Colonization rate was estimated as the total number of new taxa identified in the samples taken at the end of each week from the water containers (number of new taxa per week).

Statistical analysis. The Wilcoxon non-parametric test was used to compare the total abundance of microeukaryotes in the covered and open replicate containers, respectively, over time. In order to identify interrelationships between the containers, cluster analysis using the Bray-Curtis similarity index (Clarke \& Warwick 1994) was applied to the (presence/absence) $\times$ (samples) matrix data. For the determination of the species responsible for within-group similarities and between-group dissimilarities (Clarke \& Warwick 1994) we used similarity percentage analysis (SIMPER).

\section{RESULTS}

\section{Species richness of microeukaryotes by microscopic analysis}

A total of 147 (algae and protozoa) and 14 taxa (algae) of eukaryotic microorganisms were detected in plankton water samples from Thermaikos Bay (Table S2 in the supplement) and the university pool (Table S3 in the supplement), respectively. In air samples, a total of 20 taxa of airborne microeukaryotes (excluding fungi) were identified (Table S4 in the supplement).

A total of 29 taxa of airborne eukaryotic microorganisms were observed in the experimental water containers (Table 1). In seawater containers only the heterotrophic nanoflagellates (HNF) Bodo sp., Rynchomonas nasuta and Cafeteria minuta were detected. In the control containers, no microeukaryotes were ever observed. In the tap water containers, all 29 taxa were observed; thus, in the present study we will discuss only the tap water containers. Statistical analysis (Wilcoxon non-parametric test) revealed no significant differences between replicates, so the mean abundance of each taxon in the replicate containers is used in the results.

Only 7 out of the 29 airborne eukaryote taxa identified in experimental water containers were also identified in air samples taken with the air sampler (Table 1). Half of the airborne microeukaryotes that established active populations were autotrophs $(51.7 \%)$, most of them belonging to Chlorophyta (44.9\%). Zoomastigina and Ciliophora each comprised $17.2 \%$ of the total number of taxa.

The number of taxa found was similar in different seasons, ranging from 19 in winter to 22 in autumn. In autumn, the airborne microeukaryote community was dominated $(50 \%)$ by Chlorophyta, followed by Zoomastigina (18.2\%). In winter, Chlorophyta (47.4\%) were also dominant, followed again by Zoomastigina $(21.1 \%)$ and Ciliophora (15.8\%). In spring, the dominant taxonomic group was Chlorophyta $(42.9 \%)$, this time followed by Ciliophora (19\%) and Zoomastigina $(14.3 \%)$.

Cluster analysis separated the samplings, on the basis of species composition, into 2 groups at a similarity level of ca. 50 \% (Fig. 1). Group I consisted of samples collected in the final weeks of each experimental period either from covered containers or from open containers with high species richness. Group II included samples from the beginning of each experimental period. Two samples from the covered containers showed low similarity with the rest of the samples. SIMPER analysis indicated that the taxa constituting Group I were Bodo sp., Cafeteria minuta, Rhynchomonas nasuta, Chlamydomonas spp., Haematococcus lacustris, Amoeba spp., Pattersoniella vitiphila, Chlorella-like taxon, Scenedesmus cf. obliquus, Zygnema sp., Stichococcus sp., Grammatophora oceanica, Sorogena sp. and Amoeba cf. proteus; for Group II they were Bodo sp., Cafeteria minuta, Rhynchomonas nasuta, Haematococcus lacustris, Chlorellalike taxon and Chlamydomonas spp. Group I could be further divided into 3 subgroups with similarity $>70 \%$, corresponding to the 3 different sampling seasons (Fig. 1). 
Table 1. Airborne taxa identified in the tap water containers placed in the city of Thessaloniki. O = taxon found in open containers; $\mathrm{C}=$ taxon found in containers covered with a mesh. - : taxon absent

\begin{tabular}{|c|c|c|c|c|c|c|c|c|c|c|c|c|c|c|c|c|c|c|}
\hline \multirow[t]{2}{*}{ Taxon } & \multirow[b]{2}{*}{1} & \multirow[b]{2}{*}{2} & \multicolumn{2}{|c|}{ Autumn } & \multirow[b]{2}{*}{5} & \multirow[b]{2}{*}{6} & \multirow[b]{2}{*}{1} & \multirow[b]{2}{*}{2} & \multicolumn{2}{|c|}{ - Winter } & \multirow[b]{2}{*}{5} & \multirow[b]{2}{*}{6} & \multirow[b]{2}{*}{1} & \multirow[b]{2}{*}{2} & \multicolumn{2}{|c|}{ Spring } & \multirow[b]{2}{*}{5} & \multirow[b]{2}{*}{6} \\
\hline & & & 3 & 4 & & & & & 3 & 4 & & & & & 3 & 4 & & \\
\hline \multicolumn{19}{|l|}{ Chlorophyta } \\
\hline Chlamydomonas spp. ${ }^{\text {abc }}$ & - & $\mathrm{C}$ & $\mathrm{OC}$ & $\mathrm{OC}$ & $\mathrm{OC}$ & $\mathrm{OC}$ & - & $\mathrm{OC}$ & OC & $\mathrm{OC}$ & $\mathrm{OC}$ & $\mathrm{OC}$ & $\mathrm{O}$ & $\mathrm{O}$ & $\mathrm{OC}$ & $\mathrm{OC}$ & $\mathrm{OC}$ & $\mathrm{OC}$ \\
\hline Chlorella-like $^{\mathrm{abc}}$ & $\mathrm{OC}$ & $\mathrm{OC}$ & $\mathrm{OC}$ & $\mathrm{OC}$ & $\mathrm{OC}$ & $\mathrm{OC}$ & $\mathrm{O}$ & $\mathrm{O}$ & OC & $\mathrm{OC}$ & OC & $\mathrm{OC}$ & - & $\mathrm{O}$ & $\mathrm{O}$ & $\mathrm{OC}$ & $\mathrm{C}$ & $\mathrm{C}$ \\
\hline Chlorosarcinopsis sp. & - & - & - & - & $\mathrm{O}$ & $\mathrm{OC}$ & - & - & - & $\mathrm{C}$ & - & - & - & - & - & - & - & - \\
\hline $\begin{array}{l}\text { Chlorosarcinopsis } \\
\text { bastropiensis }\end{array}$ & - & - & - & $\mathrm{O}$ & $\mathrm{O}$ & $\mathrm{OC}$ & - & - & - & - & - & $\mathrm{O}$ & - & - & - & - & - & - \\
\hline Gloeotila sp. & - & $\mathrm{O}$ & - & - & - & - & - & - & - & - & - & - & - & - & - & - & - & - \\
\hline $\begin{array}{l}\text { Haematococcus } \\
\text { lacustris }^{\text {abc }}\end{array}$ & - & $\mathrm{C}$ & $\mathrm{OC}$ & $\mathrm{OC}$ & $\mathrm{OC}$ & $\mathrm{OC}$ & $\mathrm{O}$ & $\mathrm{OC}$ & $\mathrm{OC}$ & $\mathrm{OC}$ & $\mathrm{OC}$ & $\mathrm{OC}$ & $\mathrm{O}$ & $\mathrm{OC}$ & $\mathrm{OC}$ & $\mathrm{OC}$ & $\mathrm{OC}$ & $\mathrm{OC}$ \\
\hline Lobosphaera tirolensis & - & - & - & - & - & - & - & - & - & - & - & - & - & $\mathrm{O}$ & $\mathrm{OC}$ & $\mathrm{OC}$ & $\mathrm{OC}$ & $\mathrm{OC}$ \\
\hline $\begin{array}{l}\text { Monoraphidium } \\
\text { minutum }^{\mathrm{b}}\end{array}$ & $\mathrm{C}$ & $\mathrm{C}-$ & - & - & - & - & - & - & - & - & - & - & - & - & - & - & - & - \\
\hline Mougeotia sp. & - & - & - & $\mathrm{O}$ & $\mathrm{O}$ & $\mathrm{OC}$ & - & - & - & $\mathrm{O}$ & $\mathrm{OC}$ & $\mathrm{OC}$ & - & $\mathrm{O}$ & $\mathrm{OC}$ & $\mathrm{OC}$ & $\mathrm{C}$ & $\mathrm{C}$ \\
\hline $\begin{array}{l}\text { Scenedesmus cf. } \\
\text { obliquus }^{\mathrm{abc}}\end{array}$ & - & $\mathrm{O}$ & $\mathrm{O}$ & $\mathrm{OC}$ & $\mathrm{OC}$ & $\mathrm{OC}$ & - & $\mathrm{O}$ & $\mathrm{O}$ & - & - & - & - & $\mathrm{OC}$ & $\mathrm{OC}$ & $\mathrm{OC}$ & $\mathrm{OC}$ & $\mathrm{OC}$ \\
\hline Stichococcus sp. ${ }^{\mathrm{a}}$ & - & - & $\mathrm{O}$ & $\mathrm{O}$ & $\mathrm{O}$ & $\mathrm{OC}$ & - & - & $\mathrm{OC}$ & $\mathrm{OC}$ & $\mathrm{OC}$ & $\mathrm{OC}$ & - & $\mathrm{OC}$ & $\mathrm{OC}$ & $\mathrm{OC}$ & $\mathrm{OC}$ & OC \\
\hline Trebouxia impressa ${ }^{a}$ & - & - & - & - & - & - & - & - & - & - & - & - & - & - & $\mathrm{O}$ & $\mathrm{O}$ & $\mathrm{C}$ & $\mathrm{C}$ \\
\hline Zygnema sp. ${ }^{\mathrm{a}}$ & - & - & - & - & OC & $\mathrm{OC}$ & - & - & OC & $\mathrm{OC}$ & OC & $\mathrm{OC}$ & - & $\mathrm{O}$ & $\mathrm{OC}$ & $\mathrm{OC}$ & $\mathrm{OC}$ & OC \\
\hline \multicolumn{19}{|l|}{ Bacillariophyta } \\
\hline Grammatophora sp. ${ }^{\mathrm{b}}$ & - & - & $\mathrm{O}$ & $\mathrm{O}$ & $\mathrm{O}$ & $\mathrm{O}$ & - & $\mathrm{O}$ & $\mathrm{O}$ & $\mathrm{OC}$ & $\mathrm{OC}$ & $\mathrm{OC}$ & - & $\mathrm{O}$ & $\mathrm{O}$ & $\mathrm{O}$ & - & - \\
\hline Nitzschia $\mathrm{sp}^{\mathrm{ab}}$ & - & - & - & - & - & $\mathrm{O}$ & - & - & - & - & - & - & $\mathrm{O}$ & $\mathrm{O}$ & $\mathrm{O}$ & $\mathrm{OC}$ & $\mathrm{OC}$ & $\mathrm{OC}$ \\
\hline \multicolumn{19}{|l|}{ Ciliophora } \\
\hline Chilodonella uncinata & - & - & - & - & - & - & - & - & - & - & - & - & - & - & - & $\mathrm{O}$ & $\mathrm{OC}$ & OC \\
\hline Spathidium cf. muscicola & - & - & - & - & - & - & - & - & - & - & $\mathrm{OC}$ & $\mathrm{O}$ & - & - & - & - & - & - \\
\hline Vorticella sp. $^{\mathrm{c}}$ & - & - & - & - & - & - & - & - & - & - & - & - & - & - & $\mathrm{OC}$ & $\mathrm{OC}$ & $\mathrm{OC}$ & $\mathrm{OC}$ \\
\hline Pattersoniella vitiphila $^{\mathrm{c}}$ & - & - & $\mathrm{O}$ & $\mathrm{OC}$ & OC & $\mathrm{OC}$ & - & $\mathrm{O}$ & $\mathrm{O}$ & $\mathrm{O}$ & OC & OC & - & - & $\mathrm{OC}$ & $\mathrm{OC}$ & $\mathrm{OC}$ & $\mathrm{OC}$ \\
\hline Sorogena sp. & - & - & $\mathrm{OC}$ & $\mathrm{C}$ & $\mathrm{C}$ & $\mathrm{C}$ & - & - & - & $\mathrm{C}$ & $\mathrm{C}$ & $\mathrm{OC}$ & - & $\mathrm{OC}$ & $\mathrm{OC}$ & $\mathrm{OC}$ & $\mathrm{OC}$ & $\mathrm{OC}$ \\
\hline \multicolumn{19}{|l|}{ Zoomastigina } \\
\hline Bodo sp. ${ }^{\text {a }}$ & $\mathrm{OC}$ & $\mathrm{OC}$ & $\mathrm{OC}$ & $\mathrm{OC}$ & $\mathrm{OC}$ & $\mathrm{OC}$ & $\mathrm{O}$ & $\mathrm{OC}$ & $\mathrm{OC}$ & $\mathrm{OC}$ & $\mathrm{OC}$ & $\mathrm{OC}$ & $\mathrm{O}$ & $\mathrm{OC}$ & $\mathrm{OC}$ & $\mathrm{OC}$ & $\mathrm{OC}$ & $\mathrm{OC}$ \\
\hline Cafeteria minuta ${ }^{\mathrm{c}}$ & $\mathrm{O}$ & $\mathrm{OC}$ & $\mathrm{OC}$ & $\mathrm{OC}$ & $\mathrm{OC}$ & $\mathrm{OC}$ & $\mathrm{OC}$ & $\mathrm{OC}$ & $\mathrm{OC}$ & $\mathrm{OC}$ & $\mathrm{OC}$ & $\mathrm{OC}$ & $\mathrm{O}$ & $\mathrm{OC}$ & $\mathrm{OC}$ & $\mathrm{OC}$ & $\mathrm{OC}$ & $\mathrm{OC}$ \\
\hline Parvicorbicula cf. socialis & - & - & - & $\mathrm{OC}$ & $\mathrm{OC}$ & $\mathrm{O}$ & - & - & - & - & - & - & - & - & - & - & - & - \\
\hline Pseudobodo tremulans & - & - & - & - & - & - & - & $\mathrm{O}$ & $\mathrm{O}$ & OC & $\mathrm{OC}$ & $\mathrm{OC}$ & - & - & - & - & - & - \\
\hline Rhynchomonas nasuta ${ }^{\mathrm{c}}$ & $\mathrm{OC}$ & $\mathrm{OC}$ & $\mathrm{OC}$ & $\mathrm{OC}$ & $\mathrm{OC}$ & $\mathrm{OC}$ & $\mathrm{OC}$ & $\mathrm{OC}$ & $\mathrm{OC}$ & $\mathrm{OC}$ & $\mathrm{OC}$ & $\mathrm{OC}$ & $\mathrm{OC}$ & $\mathrm{OC}$ & $\mathrm{OC}$ & $\mathrm{OC}$ & $\mathrm{OC}$ & $\mathrm{OC}$ \\
\hline \multicolumn{19}{|l|}{ Chrysophyta } \\
\hline Spumella sp. & - & - & - & $\mathrm{O}$ & $\mathrm{OC}$ & $\mathrm{OC}$ & - & - & - & - & - & - & - & - & - & - & - & - \\
\hline Telonemia & & & & & & & & & & & & & & & & & & \\
\hline Telonema subtilis & - & - & - & - & - & - & - & - & - & - & - & - & - & - & - & $\mathrm{OC}$ & $\mathrm{O}$ & - \\
\hline Other Protozoa & & & & & & & & & & & & & & & & & & \\
\hline Amoeba cf. proteus ${ }^{\mathrm{c}}$ & - & - & - & $\mathrm{O}$ & OC & $\mathrm{OC}$ & - & - & - & $\mathrm{O}$ & $\mathrm{OC}$ & $\mathrm{OC}$ & - & - & - & $\mathrm{O}$ & $\mathrm{OC}$ & OC \\
\hline Amoeba spp. ${ }^{\mathrm{ac}}$ & - & $\mathrm{OC}$ & $\mathrm{OC}$ & $\mathrm{OC}$ & $\mathrm{OC}$ & $\mathrm{OC}$ & $\mathrm{OC}$ & $\mathrm{OC}$ & $\mathrm{OC}$ & $\mathrm{OC}$ & $\mathrm{OC}$ & $\mathrm{OC}$ & - & $\mathrm{OC}$ & $\mathrm{OC}$ & $\mathrm{OC}$ & $\mathrm{OC}$ & $\mathrm{OC}$ \\
\hline
\end{tabular}

\section{Species richness of microeukaryotes by molecular analysis}

According to Good's C estimator for the library clone coverage, an asymptotic curve $>0.80$ was reached in autumn and winter, and 0.60 in spring (Fig. S1 in the supplement). A total of 22, 23 and 16 eukaryotic 18S rRNA inserts in clone plasmids, sequenced from samples of all 3 seasons, were attributed to 11 unique phylotypes based on a $\geq 98 \%$ similarity cut-off limit (Table S5, Fig. S2). In all seasons, the 18S rRNA gene clone libraries were dominated by phylotype Th260208_9, which was closely related to the ciliate Pattersoniella vitiphila. Overall, for all seasons, the dominant phylotypes belonged to Ciliophora $(68.9 \%)$ and Chlorophyta $(16.4 \%)$, although additional phylotypes may have been recovered by using supplementary sets of primers (Stoeck et al., 2006). In spite of the results from Good's estimator, the low sequencing effort might have resulted in missing some percentage of the diversity in the water containers.

Fungal phylotypes, as well as 1 Oomycota phylotype, were also detected and are mentioned in order to make the phylogenetic analysis complete (Table S5, Fig. S2). However, this paper is not focused on describing and discussing these taxa, so the results concerning these phylotypes will be presented elsewhere. 


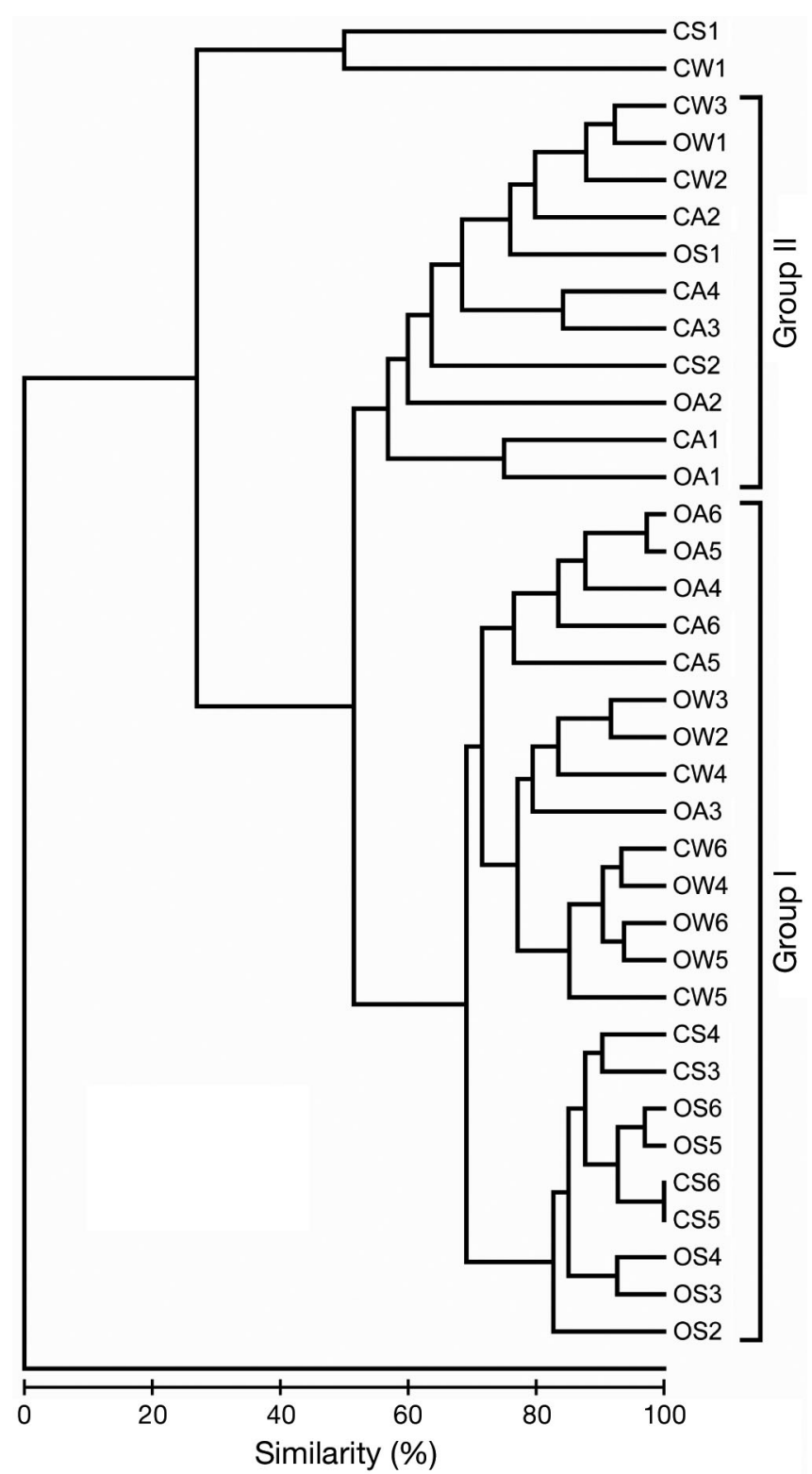

Fig. 1. Dendrogram for clustering of airborne microeukaryote communities found in tap water containers, based on BrayCurtis similarities. O: open containers, C: covered containers; A: autumn, W: winter, S: spring. Numbers depict week of sampling

\section{Colonization potential and characteristics of airborne colonists}

The total number of new taxa found in the tap water containers each week ranged from 9 to 0 . The highest colonization rate was observed in spring and was due to Chlorophyta, with 6 new taxa added per week. Zoomastigina exhibited the second highest colonization rate ( 3 new taxa added per week) in the first week of each experimental period followed by Ciliophora ( 2 new taxa added per week). In the first 2 wk of each experimental period, the colonization rate was high (4 to 6 new taxa added in the first week and 5 to 9 in the second) while during the last 2 wk the colonization rate dropped, especially in spring, when no new taxa were added in the final $2 \mathrm{wk}$ (Fig. 2).

The airborne microorganisms were observed as single cells (Chlorella-like taxon, Nitzschia spp., HNF such as Bodo sp., Cafeteria minuta and Rynchomonas nasuta and other protozoa, like the ciliate Pattersoniella vitiphila), coenobia of cells (Scenedesmus cf. obliquus, Trebouxia impressa) or filamentous vegetative forms (Stichococcus sp., Mougeotia sp. and Zygnema sp.). The categories of the airborne colonists found - based on the frequency of appearance, abundance, generation time and individual size-are presented in Table 2. Small-sized species constituted $53.1 \%$ of the total number of airborne microeukaryote species. Four out of 5 of the most frequently observed airborne microeukaryotes (Table 2) were small-sized species (Haematococcus lacustris, Bodo sp., Cafeteria minuta and Rhynchomonas nasuta). In addition, all 4 species reached high abundances in all 3 seasons, but only HNF taxa (Bodo sp., Cafeteria minuta and Rhynchomonas nasuta) had generation times shorter than $1 \mathrm{~d}$. Another frequently observed taxon was Amoeba, which also reached high abundances in autumn and winter with generation times between 1 and $2 \mathrm{~d}$. Pattersoniella vitiphila had a moderate frequency of appearance and a moderate generation time, with high abundance values throughout the study period, despite its large size.

In total, only 8 taxa of the colonists in the water containers were simultaneously observed in the nearby aquatic systems of Thermaikos Bay (Bodo sp., Cafeteria minuta, Parvicorbicula cf. socials, Rynchomonas nasuta and Grammatophora oceanica) and in the university pool (Nitzschia spp., Scenedesmus cf. obliquus and Zygnema sp.) (Table S2).

\section{Life cycles of Pattersoniella vitiphila and Haematococcus lacustris}

In all seasons after the 3rd wk of the experiment, cysts belonging to the ciliate Pattersoniella vitiphila were detected (Fig. 3A). The cysts were observed to start excystment (Fig. 3B) after $1 \mathrm{wk}$, producing actively swimming ciliates, identified by microscopical analysis, belonging to the species Pattersoniella vitiphila (Fig. $3 C)$. The cells were elongate in accordance with the description of the species in Foissner \& Stoeck (2008). Soon after the excystment, a pair of adult individuals was commonly observed attached with the posterior to the anterior end, indicating sexual reproduction (Fig. 3D). The life cycle was complete within $2 \mathrm{wk}$. 

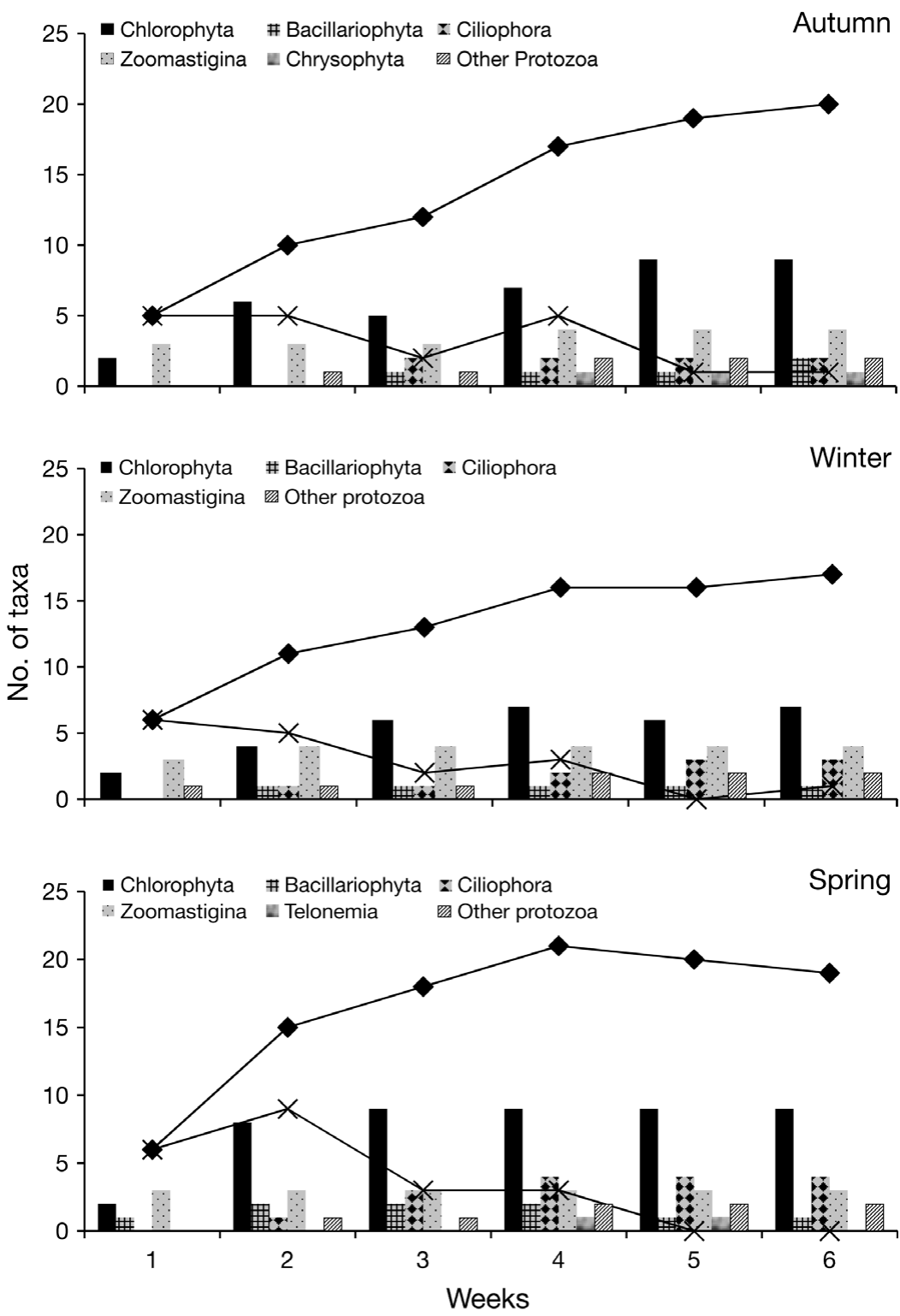

Fig. 2. Number of total microeukaryote taxa $(\diamond)$ and number of new taxa $(X)$ found in open containers with tap water. Bars represent the number of taxa in each major taxonomic group for $6 \mathrm{wk}$ in all 3 seasons

The chlorophyte Haematococcus lacustris also exhibited a complex life cycle in the water containers. Spherical cysts with red-brick coloration (Fig. 3E) were detected in the first week of the experiment in all seasons. These quickly divided into 2-celled (Fig. 3F), 4celled (Fig. 3G), and rarely 8-celled cysts. The flagellated cells had a gelatinous sheath not allowing free movement. However, the most mature cysts were somewhat motile, exhibiting a desultory movement. In the green adult individuals, the gelatinous sheath covered the cell, whereas the 2 equal flagella, although attached to each other inside the sheath, were separated and moving freely outside the membrane (Fig. 3H).

\section{Established food webs}

In all seasons the abundance ratio autotrophs:heterotrophs was $<1$ in the initial phase of the colonization (Week 1), indicating dominance of heterotrophic microeukaryotes. The $<1$ ratio was maintained in autumn and winter throughout $4 \mathrm{wk}$. However in spring, the ratio changed from $<1$ to $>15$ through the 6 wk period, suggesting transition from heterotroph to autotroph dominance (Fig. 4, left-hand). The predator-prey density relations are shown in Fig. 4, right-hand. In all seasons predator abundance increased as prey abundance increased until Week 5 in autumn and winter and Week 4 in spring. In autumn and winter, in Week 6 of the experiment, predator abundance dropped as prey abundance continued to increase. In spring, a similar decrease in the predator abundance was observed earlier, starting in Week 5 and stabilizing to a plateau.

Autotroph colonists reached high abundances in all seasons at the 6th week of the colonization experiment with the Chlorophyta Haematococcus lacustris, Scenedesmus cf. obliquus, Chlorella-like taxon, Chlamydomonas spp. and Stichococcus sp. dominating the autotroph community. HNF and larger $(>50 \mu \mathrm{m})$ protozoa (Pattersoniella vitiphila, Vorticella sp. and Amoeba spp.) also exhibited high numbers. In autumn, $H$. lacustris was the dominant autotroph in the water containers, reaching $>50000$ cells $\mathrm{ml}^{-1}$ in Week 6, followed by Stichococcus sp. (20000 cells ml ${ }^{-1}$ ). HNF reached 25000 cells $\mathrm{ml}^{-1}$, while very common were the ciliate Pattersoniella vitiphila (200 cells $\mathrm{ml}^{-1}$ ) and species belonging to Amoeba (>1000 cells ml ${ }^{-1}$ ). In winter, apart from $H$. lacustris, particularly high densities were observed for the chlorophyte Chlamydomonas spp. (40000 cells $\mathrm{ml}^{-1}$ ). HNF reached very high abundance in the final weeks of the experimental period (up to 200000 cells $\mathrm{ml}^{-1}$ ) and $P$. vitiphila and Amoeba spp. dominated the larger heterotrophic microeukayotes. In spring, while $H$. lacustris was still present and growing in number, another chlorophyte came to dominate the community of the water containers: Scenedesmus cf. obliquus reached very high numbers in Week 6 (140000 cells 
Table 2. Assignment of airborne microeukaryotes, found in the water containers in all 3 seasons, into categories of frequency, abundance, generation time and individual size class. $\mathrm{H}=$ high, $\mathrm{M}=$ moderate, and $\mathrm{L}=$ low. SGT $=$ short generation time, MGT = moderate generation time, and LGT = long generation time. $\mathrm{SS}=$ small size, $\mathrm{MS}=$ moderate size, and LS $=$ large size . Aut. = autumn, win. $=$ winter, spr. = spring. - : zero abundance

\begin{tabular}{|c|c|c|c|c|c|c|c|c|}
\hline \multirow{2}{*}{ Taxa } & \multirow{2}{*}{ Frequency of occurrence } & \multicolumn{3}{|c|}{ Abundance } & \multicolumn{3}{|c|}{ Generation time } & \multirow[t]{2}{*}{ Size class } \\
\hline & & Aut. & Win. & Spr. & Aut. & Win. & Spr. & \\
\hline Rynchomonas nasuta $^{a}$ & $\mathrm{H}$ & $\mathrm{H}$ & $\mathrm{H}$ & $\mathrm{H}$ & SGT & SGT & LGT & SS \\
\hline Bodo sp. ${ }^{\mathrm{a}}$ & $\mathrm{H}$ & $\mathrm{H}$ & $\mathrm{H}$ & $\mathrm{H}$ & SGT & SGT & LGT & SS \\
\hline Cafeteria minuta $^{\mathrm{a}}$ & $\mathrm{H}$ & $\mathrm{H}$ & $\mathrm{H}$ & $\mathrm{H}$ & SGT & SGT & LGT & SS \\
\hline Haematococcus lacustris & $\mathrm{H}$ & $\mathrm{H}$ & $\mathrm{H}$ & $\mathrm{H}$ & MGT & LGT & MGT & SS \\
\hline Amoeba spp. & $\mathrm{H}$ & $\mathrm{H}$ & $\mathrm{H}$ & M & MGT & MGT & MGT & MS \\
\hline Sorogena sp. & M & $\mathrm{L}$ & $\mathrm{L}$ & $\mathrm{L}$ & LGT & MGT & LGT & SS \\
\hline Scenedesmus cf. obliquus ${ }^{\mathrm{b}}$ & M & $\mathrm{M}$ & $\mathrm{L}$ & $\mathrm{H}$ & MGT & LGT & SGT & SS \\
\hline Chlamydomonas spp. & M & $\mathrm{L}$ & $\mathrm{H}$ & M & MGT & MGT & LGT & SS \\
\hline Grammatophora oceanica $^{a}$ & M & $\mathrm{L}$ & $\mathrm{L}$ & $\mathrm{L}$ & MGT & MGT & MGT & SS \\
\hline Chlorella sp. & M & M & $\mathrm{H}$ & $\mathrm{L}$ & MGT & SGT & LGT & SS \\
\hline Stichococcus sp. & M & $\mathrm{H}$ & $\mathrm{H}$ & $\mathrm{H}$ & MGT & SGT & MGT & MS \\
\hline Amoeba cf. proteus & M & $\mathrm{L}$ & $\mathrm{L}$ & $\mathrm{L}$ & MGT & MGT & MGT & LS \\
\hline Mougeotia sp. & M & $\mathrm{H}$ & $\mathrm{H}$ & M & MGT & MGT & MGT & LS \\
\hline Zygnema sp. ${ }^{\mathrm{b}}$ & M & $\mathrm{H}$ & $\mathrm{H}$ & $\mathrm{H}$ & MGT & MGT & MGT & $\mathrm{LS}$ \\
\hline Pattersoniella vitiphila & M & $\mathrm{H}$ & $\mathrm{H}$ & $\mathrm{H}$ & LGT & LGT & LGT & LS \\
\hline Lobosphaera tirolensis & $\mathrm{L}$ & - & - & $\mathrm{L}$ & - & - & MGT & SS \\
\hline Trebouxia impressa & $\mathrm{L}$ & - & - & $\mathrm{L}$ & - & - & MGT & SS \\
\hline Monoraphidium minutum & $\mathrm{L}$ & $\mathrm{L}$ & - & - & MGT & - & - & SS \\
\hline Nitzschia spp. ${ }^{\mathrm{b}}$ & $\mathrm{L}$ & $\mathrm{L}$ & - & $\mathrm{H}$ & MGT & - & SGT & SS \\
\hline Parvicorbicula cf. socialis ${ }^{\mathrm{a}}$ & $\mathrm{L}$ & $\mathrm{L}$ & - & - & LGT & - & - & SS \\
\hline Pseudobodo tremulans & $\mathrm{L}$ & - & $\mathrm{L}$ & - & - & LGT & - & SS \\
\hline Spumella sp. & $\mathrm{L}$ & $\mathrm{L}$ & - & - & LGT & - & - & SS \\
\hline Telonema subtilis & $\mathrm{L}$ & - & - & $\mathrm{L}$ & - & - & LGT & SS \\
\hline Chlorosarcinopsis sp. & $\mathrm{L}$ & $\mathrm{L}$ & - & - & LGT & - & - & MS \\
\hline $\begin{array}{l}\text { Chlorosarcinopsis } \\
\text { bastropiensis }\end{array}$ & $\mathrm{L}$ & $\mathrm{L}$ & - & - & LGT & - & - & MS \\
\hline Spathidium cf. muscicola & $\mathrm{L}$ & - & M & - & - & MGT & - & MS \\
\hline Gloeotila sp. & $\mathrm{L}$ & M & - & - & MGT & - & - & LS \\
\hline Chilodonella uncinata & $\mathrm{L}$ & - & - & $\mathrm{L}$ & - & - & LGT & LS \\
\hline Vorticella sp. & $\mathrm{L}$ & - & - & $\mathrm{H}$ & - & - & LGT & LS \\
\hline
\end{tabular}
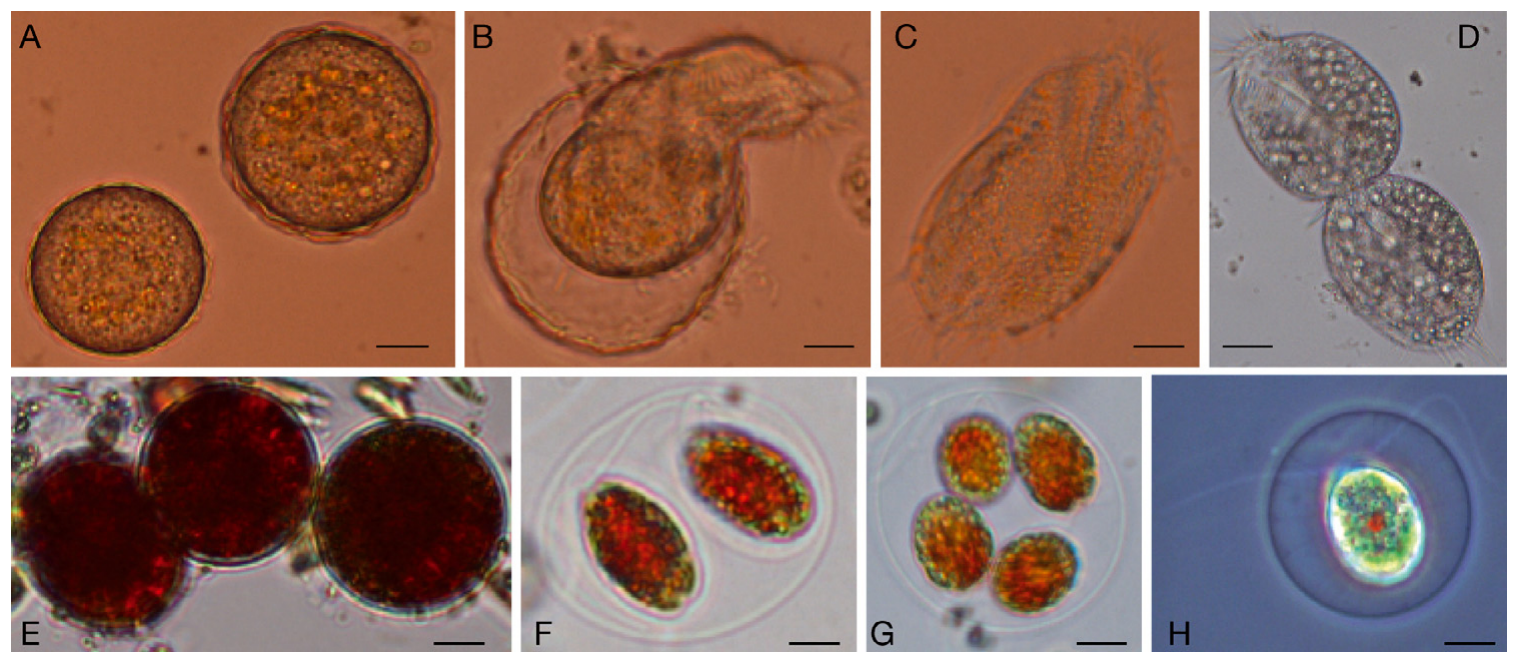

Fig. 3. Pattersoniella vitiphila and Haematococcus lacustris. Microscopic eukaryotes found in water containers. Light micrographs (phase contrast) of live cells. (A) Cysts of the ciliate $P$. vitiphila. (B) Excystment of $P$. vitiphila. (C) Free-swimming young individual of $P$. vitiphila. (D) Two individuals of $P$. vitiphila attached with the posterior to the anterior end, indicating sexual reproduction. (E) Cysts of the chlorophyte H. lacustris. (F) Two-celled cysts of H. lacustris. (G) Four-celled cysts of H. lacustris.

(H) Free-swimming individual of $H$. lacustris. Scale bars for A-C $=10 \mu \mathrm{m}$, for $\mathrm{D}=50 \mu \mathrm{m}$, and for $\mathrm{E}-\mathrm{H}=5 \mu \mathrm{m}$ 


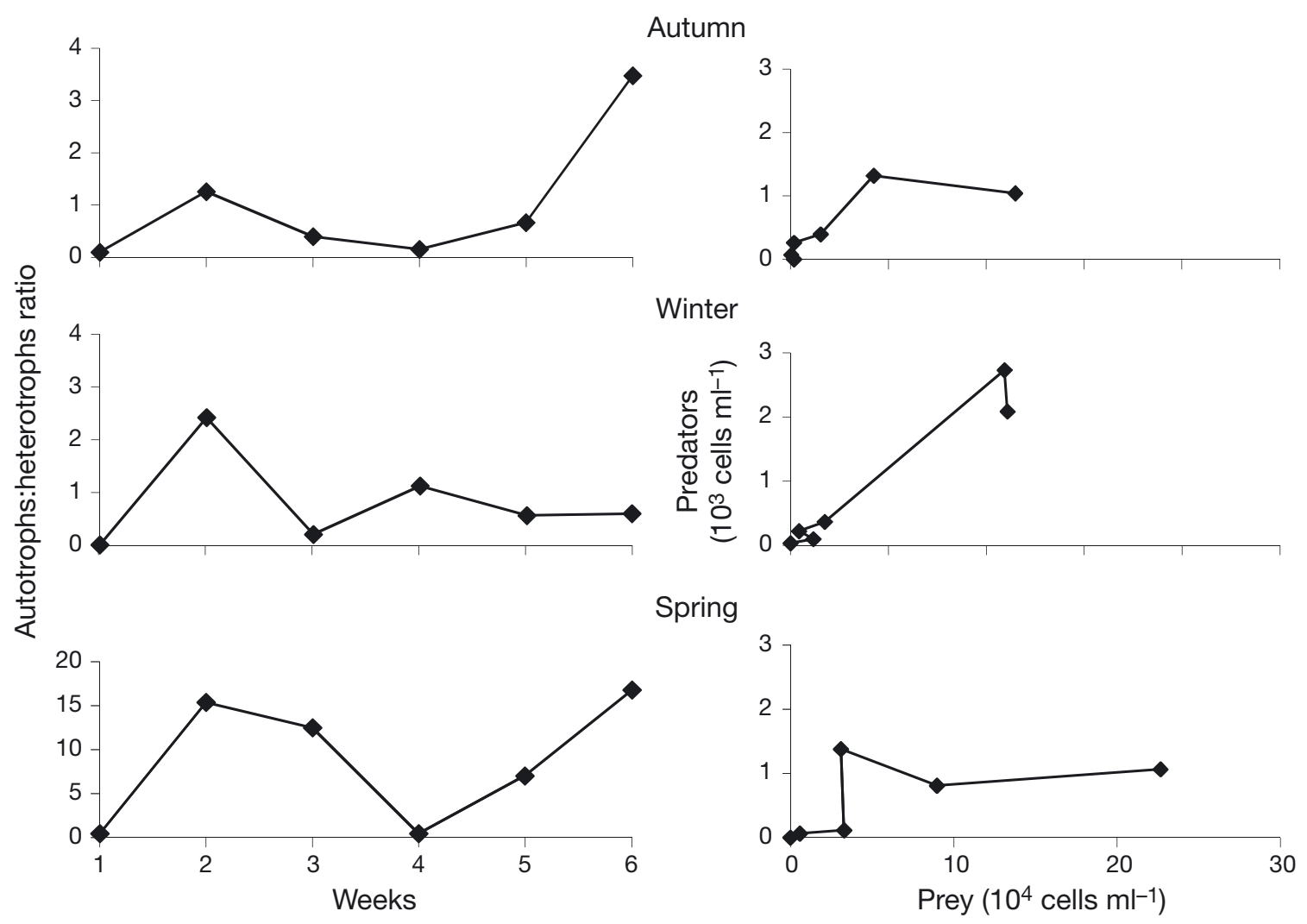

Fig. 4. Ratio of autotrophs to heterotrophs and predator-prey abundance relationship (cells $\mathrm{ml}^{-1}$ ) in the 6 wk experiments in tap water containers during the 3 seasons

$\mathrm{ml}^{-1}$ ). The ciliate Vorticella sp. appeared for the first time among the heterotrophs and dominated, reaching 500 cells $\mathrm{ml}^{-1}$ (Fig. 5).

Trophic interactions between HNF, the dominant larger heterotrophic microeukaryotes (Pattersoniella vitiphila and Amoeba spp.) and autotrophs (Haematococcus lacustris, Scenedesmus cf. obliquus, Chlorellalike taxon and Chlamydomonas spp.) were observed in the established food web. Large heterotrophic microeukaryotes (mainly P. vitiphila [Fig. 6A], Amoeba cf. proteus [Fig. 6B] and Vorticella sp.) were observed to feed on dominant HNF (Rynchomonas nasuta, Cafeteria minuta and Bodo sp.), and on abundant Chlorophyta taxa (mainly H. lacustris, but also on a Chlorellalike taxon, S. cf. obliquus and Chlamydomonas spp.).

\section{DISCUSSION}

Microeukaryotes are excellent model organisms for examining colonization processes, and most experiments use source pools of microbial species from natural freshwater systems (e.g. Pratt et al. 1985). In the present study, we examined the composition and succession of airborne microeukaryote communities established in experimental water containers in a coastal, urban environment, the city of Thessaloniki, Greece, and the established food webs through trophic relationships and features of the life cycle described for the most dominant colonists.

Near the sampling site of the present study there is a large marine system, Thermaikos Bay, and a small freshwater pool. The characteristics of the sampling site are essential determinants of the diversity and dynamics of airborne microeukaryotes (Sharma et al. 2007). Nearby aquatic systems in rural areas could serve as major natural sources of airborne microorganisms (e.g. Chrisostomou et al. 2009). However, in the present study, in the urban area of Thessaloniki, only 8 airborne species were detected in simultaneous examinations of microeukaryotes in the nearby aquatic systems - and from them, only 5 were found from Thermaikos Bay. One possible explanation for fewer marine microbial colonists is that the airborne marine microeukaryotes were less diverse than their freshwater counterparts during the whole period of the 
Autumn
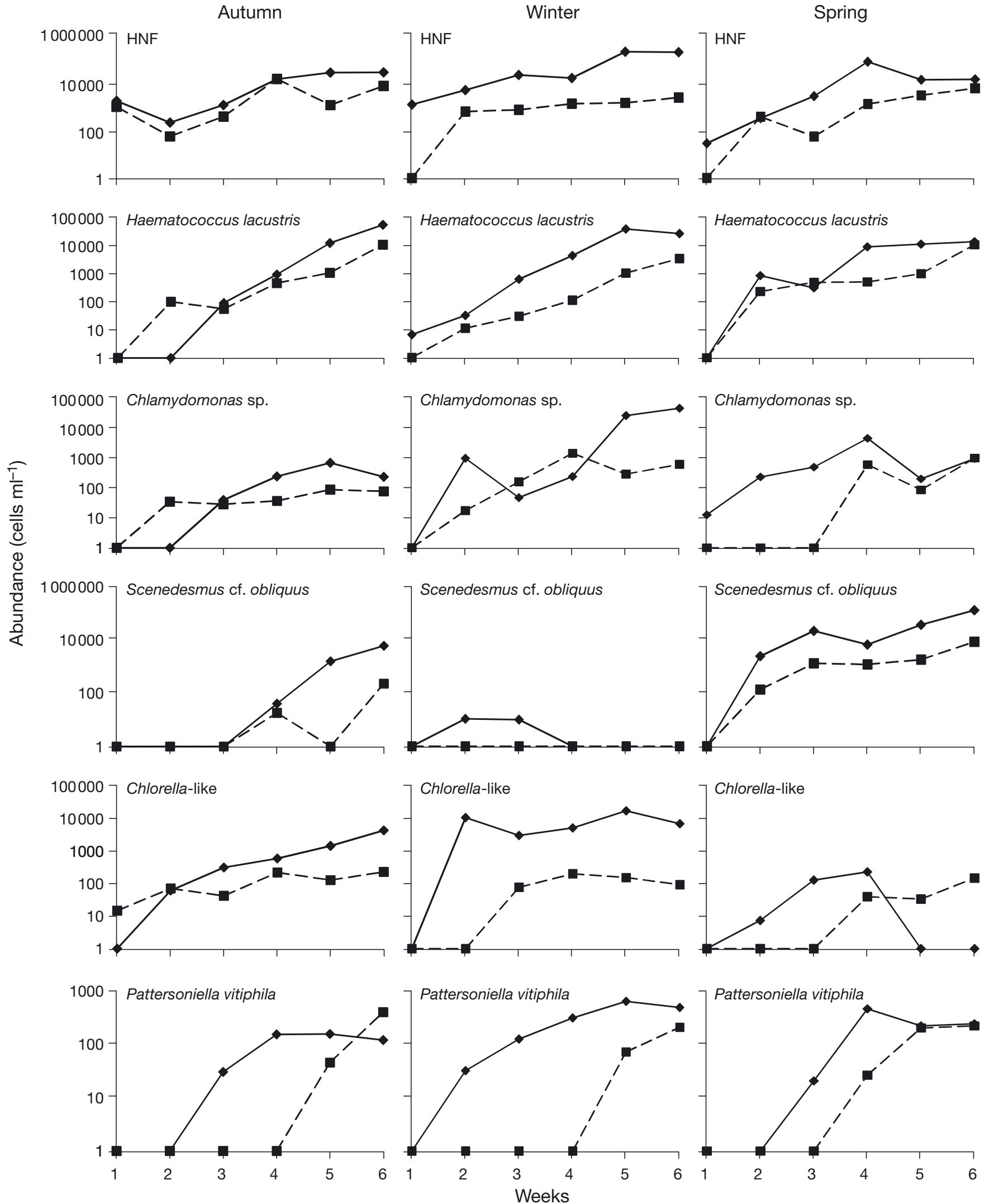

Fig. 5. Abundance of the dominant microeukaryotes in the water containers in the 6 wk experiments in 3 seasons (autumn, winter and spring). Solid line: open containers, dashed line: covered containers. $y$-axis: logarithmic scale 


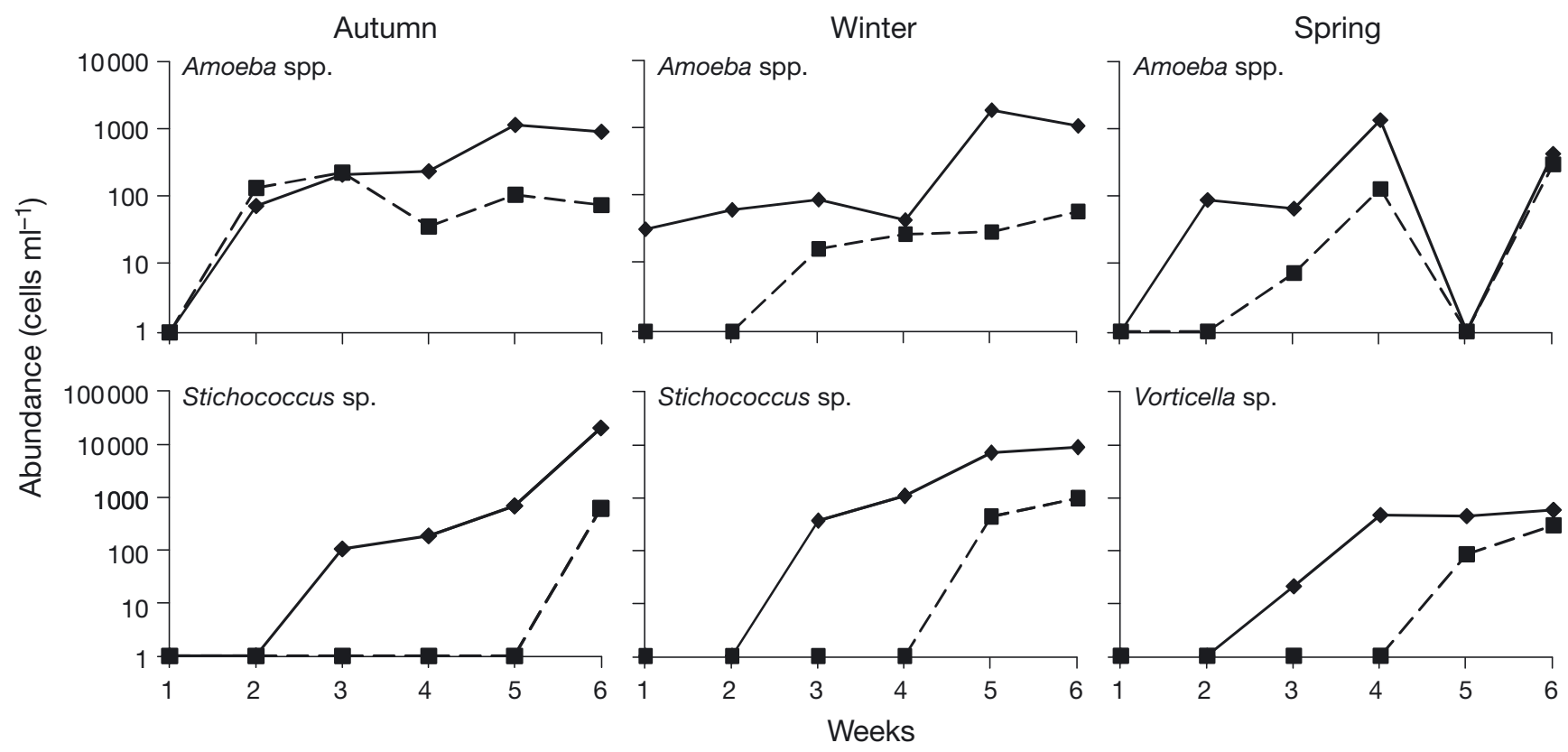

Fig. 5. (continued)

study. Similar results have been reported from aerobiological studies worldwide (Genitsaris et al. (2011)). A local water source for the majority of airborne microeukaryotes is not likely in the present study, pointing towards a more possible long-distance dispersal of microorganisms of remote water origin (Finlay \& Clarke 1999). Nevertheless, a local pool of soil microeukaryotes that can also act as a natural source of airborne microorganisms can be important (Brown et al. 1964).
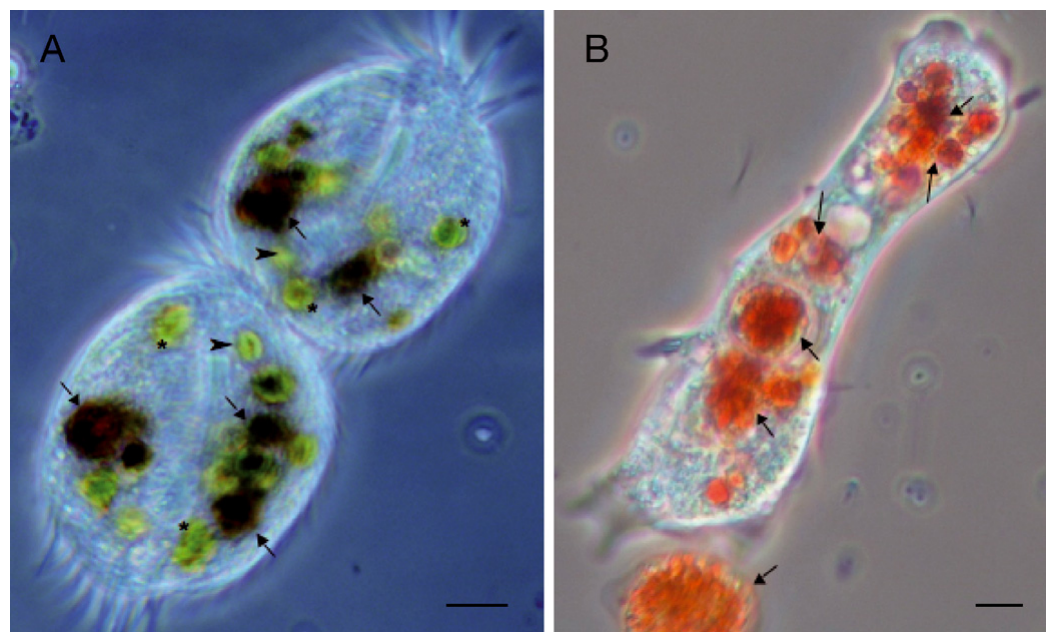

Fig. 6. Microscopic eukaryotes: key components of the food web. Light micrographs (phase contrast) of live cells. (A) Individuals of the ciliate Pattersoniella vitiphila with food particles. (B) Individual of Amoeba cf. proteus with food particles. Arrows represent Haematococcus lacustris particles, arrowheads represent Scenedesmus cf. obliquus particles, and asterisks ( $\left.{ }^{*}\right)$ represent Chlorellalike particles. Scale bar for $A=50 \mu \mathrm{m}$ and for $\mathrm{B}=10 \mu \mathrm{m}$
Open and covered tap water containers were not seasonally separated according to cluster analysis, supporting a similar pattern of colonization and growth of airborne microeukaryotes in both treatments. This finding suggests that the wind is a more important dispersal agent compared to animal vectors. However, it should be considered that the water containers were of a relatively small size to attract large animals, such as birds. Animal vectors are considered to be an essential microbial dispersal force (Figuerola \& Green 2002, Green \& Bohannan 2006), although Cohen \& Shurin (2003) investigated mechanisms of dispersal in freshwater zooplankton and found that animalmediated dispersal is less important than wind dispersal.

Throughout the study period, we observed a decrease in new taxa colonizing the water containers as the total number of species increased - indicating a stabilization of the colonization rate close to zero in a 6 wk period. According to MacArthur \& Wilson's island biogeography theory (MacArthur \& Wilson 1963, 1967), the rate of new species entering a newly formed system by colonization falls as the number of species in the system increases because the chance that an immigrant is already present in the system increases. The scarce available data on colonization of airborne microeukaryotes suggest that 
there is a rapid colonization of microorganisms in experimental jars at the beginning of the experiment - but that the number of species quickly stabilizes to a plateau (Maguire Jr. 1963). Such colonization processes occur in the order of days to weeks for many opportunistic species (Cohen \& Shurin 2003).

The airborne microeukaryotes in the tap water containers were dominated, in terms of the number of species, by members of the Chlorophyta, which have been reported to dominate the airborne microorganisms of temperate regions (Brown et al. 1964, Sharma et al. 2007). Additionally, Chlorophytes are the first colonists in artificial ponds (Williams et al. 1994), and they are considered as potential inocula for colonization of Antarctica as climate change continues to uncover new systems (Marshall \& Chalmers 1997). In addition, Chrisostomou et al. (2009) also observed high number of chlorophytes in a study of air-dispersed phytoplankton colonizing water containers in a rural area. A large number of airborne protozoa in the water containers were also observed in the present study, including taxa belonging to HNF, amoebae and ciliates. Among them, the cosmopolitan HNF Bodo sp., Cafeteria minuta, Rynchomonas nasuta and Parvicorbicula cf. socials might be of local origin from the nearby Thermaikos Bay. The genus Bodo and amoebas are also known airborne eukaryotes (Rivera et al. 1992, Rogerson \& Detweiler 1999). Common species in these studies were detected earlier by Schlichting $(1964,1969)-$ which, together with our results, suggest that certain taxa, like amoebae and Bodo spp. are common in the air of different biogeographic regions, independently of the prevailing environmental factors.

The HNF Bodo sp., Cafeteria minuta and Rynchomonas nasuta and the chlorophytes Haematococcus lacustris, a Chlorella-like taxon, Scenedesmus cf. obliquus and Stichococcus sp. were present in all 3 seasons under a wide range of meteorological conditions, such as rainfall, sunshine, changes in air temperature, relative humidity and wind speed. Taxa belonging to Chlorella, Scenedesmus and Stichococcus also exhibit no seasonal preferences, although they can be frequently detected in samples taken in the autumn, winter and spring (Sharma et al. 2006). In our study, microeukaryotes with no seasonal preferences were capable of successful dispersal and colonization of new habitats due to small and resistant unicellular forms (Cairns et al. 1969, Rivera et al. 1992) and a short generation time (Dolan 2005). It is considered that a spheroid unicell of up to $12 \mu \mathrm{m}$ in diameter, as found, for example, in species of Chlorella and Stichococcus, is the ideal airborne alga (Roy-Ocotla \& Carrera 1993). However, the most successful airborne colonist was $H$. lacustris with a cell size larger than that ideal for algae.
Haematococcus species have been commonly found in ephemeral water pools in rural and urban areas (Proctor 1957) and phytotelmata (Gebühr et al. 2006). Its remarkable life cycle observed in this study, which includes resistant cysts and swift reproduction stages when encountering favourable conditions, makes it successful at dispersal and colonization. Although Haematococcus seems to be capable of exploiting newly formed systems, it is unable to withstand the competition of the subsequent, more efficient colonists such as Scenedesmus and Chlamydomonas (Proctor 1957). However, in the present study such inhibition of Haematococcus by the simultaneous increase of Chlamydomonas sp. and Scenedesmus cf. obliquus was not observed.

The possible deposition of atmospheric contaminants could have a significant effect on microbial communities in the containers. According to Munawar \& Weisse (1989), the relative importance of the microbial loop, and the way it functions, could be early indicators of human disturbance of aquatic biological communities. Thus, the atmospheric deposition of contaminants could have a selective effect on the structure of the microbial food web.

An allochthonous input in water containers of both viable cysts of microorganisms and detritus was observed in all seasons, where HNF were the first colonists. The heterotrophic stage in the initial phase of colonization preceding the primary community assembly is also observed on land (Hodkinson et al. 2002). The water containers resembled Aeolian ecosystems, as any inputs, abiotic as well as biotic, were airborne and as a detritus-based food web, similar to Aeolian ecosystems (Polis et al. 1997), was established in all water containers in a very short period of time.

At least 3 functional groups participating in discrete food webs in the water containers were distinguished: the predators (mainly the ciliate Pattersoniella vitiphila), the primary producers (prey organisms Haematococcus lacustris, Chlamydomonas spp., a Chlorella-like taxon and Scenedesmus cf. obliquus), and the HNF which were consumed by the predators, but also feed on bacteria (Weisse 2002). Food web components in all seasons were similar, although meteorological parameters varied considerably within the 3 seasons. Moreover, a large population of microbial food web components was observed in all seasons, suggesting that energy input was not a limiting factor controlling the food web structure. Food web structure is determined by limitations of energy and dynamic constraints (Jenkins et al. 1992). The predators showed a functional response to increasing prey density in autumn and winter at high prey densities. Finally, the predator density might be regulated by other factors, 
such as the availability of space (Lampert \& Sommer 2007). However, in spring, predator-prey populations didn't show the same response, possibly due to complexity of the microeukaryote community (higher diversity of key prey and predators).

The common top predator of the microbial food webs in all seasons was the ciliate Pattersoniella vitiphila. $P$. vitiphila is found in terrestrial habitats and, in particular, was detected in evergreen rainforests in Australia (Foissner 1997). The present study is the first record of airborne $P$. vitiphila and its life-cycle. The species was transferred in the form of cysts, which then started excystment, producing young individuals. Molecular analysis revealed that the $P$. vitiphila clone in our samples was very similar (99\%) to the clone reported from the neighbouring lake Koronia (Genitsaris et al. 2009), suggesting a common source proximate to both sites. We observed $P$. vitiphila to feed mainly on the chlorophyte Haematococcus lacustris, which seems to be a very nutritious prey because of the large amounts of the ketocarotenoid astaxanthin it contains (Harker et al. 1996). Haematococcus taxa have received a lot of attention recently, mainly because of their ability to synthesize large amounts of astaxanthin (Harker et al. 1996) - a substance widely used commercially to colour the flesh of salmon in aquaculture, and also in other applications for human health and nutrition (Guerin et al. 2003). Despite predation by larger protozoa (e.g. P. vitiphila, Amoeba spp.) HNF rapidly reached vast populations (up to 200000 cells $\mathrm{ml}^{-1}$ ) due to their high growth rates (e.g. Finlay \& Esteban 1998). Our results indicate that airborne ciliates and HNF play a fundamental functional role in microbial communities established in experimental water containers, similar to their role in freshwater and marine ecosystems (Sherr \& Sherr 1994).

In conclusion, in the present study, we investigated airborne freshwater and marine microeukaryotes as sources for the colonization of new experimental aquatic habitats. The airborne microeukaryote colonists comprised few taxa observed in the nearby aquatic systems, whereas the majority of colonists are commonly found in many different biogeographic regions. Chlorophyta was the most species-rich group. The HNF Bodo sp., Cafeteria minuta and Rynchomonas nasuta, the algae Haematococcus lacustris, a Chlorella-like taxon, Scenedesmus cf. obliquus and the ciliate Pattersoniella vitiphila were present in all 3 seasons, indicating capabilities of successful dispersal and colonization of new habitats under a wide range of meteorological conditions. HNF comprised the heterotrophic initial succession phase of colonization, as pioneers. The heterotrophic and autotrophic colonists rapidly developed functional roles in the new habitats, establishing similar food webs in all seasons. For both the common top predator $P$. vitiphila and the key prey H. lacustris, resistant cysts were the initial stages of their complex life cycle; which we described in this study.

Acknowledgements. The authors are grateful to the 3 reviewers for their constructive comments that improved the manuscript. The authors are also grateful to T. Mavrommatis for kindly providing meteorological data. We thank E. Michaloudi for suggesting improvements on an earlier version of this manuscript.

\section{LITERATURE CITED}

Brown RM Jr, Larson DH, Bold HC (1964) Airborne algae: their abundance and heterogeneity. Science 143:583-585

Cairns J Jr, Dahlberg ML, Dickson KL, Smith N, Waller WT (1969) The relationship of fresh-water protozoan communities to the MacArthur-Wilson equilibrium model. Am Nat 103:439-454

Chrisostomou A, Moustaka-Gouni M, Sgardelis S, Lanaras T (2009) Air-dispersed phytoplankton in a Mediterranean river-reservoir system (Aliakmon-Polyphytos, Greece). J Plankton Res 31:877-884

Clarke KR, Warwick RM (1994) Similarity-based testing for community pattern: the two-way layout with no replication. Mar Biol 118:167-176

Cohen GM, Shurin JB (2003) Scale-dependence and mechanisms of dispersal in freshwater zooplankton. Oikos 103: 603-617

Corliss JO, Esser SC (1974) Comments on the role of the cyst in the life cycle and survival of free-living protozoa. Trans Am Microsc Soc 93:578-593

Damialis A, Halley JM, Gioulekas D, Vokou D (2007) Longterm trends in atmospheric pollen levels in the city of Thessaloniki, Greece. Atmos Environ 41:7011-7021

> Dawson SC, Pace NR (2002) Novel Kingdom-level eukaryotic diversity in anoxic environments. Proc Natl Acad Sci USA 99:8324-8329

Dickerson JE Jr, Robinson JV (1984) The assembly of microscopic communities: patterns of species importance. Trans Am Microsc Soc 103:164-171

> Dickerson JE Jr, Robinson JV (1985) Microcosms as islands: a test of the MacArthur-Wilson equilibrium theory. Ecology 66:966-980

> Dolan JR (2005) An introduction to the biogeography of aquatic microbes. Aquat Microb Ecol 41:39-48

> Figuerola J, Green AJ (2002) Dispersal of aquatic organisms by waterbirds: a review of past research and priorities for future studies. Freshw Biol 47:483-494

Finlay BJ (2002) Global dispersal of free-living microbial eukaryote species. Science 296:1061-1063

Finlay BJ, Clarke KJ (1999) Apparent global ubiquity of species in the protist genus Paraphysomonas. Protist 150: 419-430

Finlay BJ, Esteban GF (1998) Freshwater protozoa: biodiversity and ecological function. Biodivers Conserv 7: 1163-1186

Foissner W (1997) Soil ciliates (Protozoa: Ciliophora) from evergreen rain forests of Australia, South America and Costa Rica: diversity and description of new species. Biol Fertil Soils 25:317-339

Foissner W, Stoeck T (2008) Morphology, ontogenesis and molecular phylogeny of Neokeronopsis (Afrokeronopsis) aurea nov. subgen., nov. spec. (Ciliophora: Hypotricha), a new African flagship ciliate confirms the CEUU hypothesis. Acta Protozool 47:1-33 
Gebühr C, Pohlon E, Schmidt AR, Küsel K (2006) Development of microalgae communities in the phytotelmata of allochthonous populations of Sarracenia purpurea (Sarraceniaceae). Plant Biol 8:849-860

- Genitsaris S, Kormas KA, Moustaka-Gouni M (2009) Microscopic eukaryotes living in a dying lake (Lake Koronia, Greece). FEMS Microbiol Ecol 69:75-83

Genitsaris S, Kormas KA, Moustaka-Gouni M (2011) Airborne algae and cyanobacteria: occurrence and related health effects. Front Biosc (in press) doi:10.2741/E285

Gioulekas D, Damialis A, Papakosta D, Spieksma F, Giouleka P, Patakas D (2004) Allergenic fungi spore records (15 years) and sensitization in patients with respiratory allergy in Thessaloniki-Greece. J Investig Allergol Clin Immunol 14:225-231

Good IJ (1953) The population frequencies of species and the estimation of population parameters. Biometrika 43:45-63

Green J, Bohannan BJM (2006) Spatial scaling of microbial biodiversity. Trends Ecol Evol 21:501-507

> Guerin M, Huntley ME, Olaizola M (2003) Haematococcus astaxanthin: applications for human health and nutrition. Trends Biotechnol 21:210-216

> Hamilton WD, Lenton TM (1998) Spora and Gaia: how microbes fly with their clouds. Ethol Ecol Evol 10:1-16

> Harker M, Young AJ, Tsavalos AJ (1996) Factors responsible for astaxanthin formation in the chlorophyte Haematococcus pluvialis. Bioresour Technol 55:207-214

> Hodkinson ID, Webb NR, Coulson SJ (2002) Primary community assembly on land - the missing stages: Why are the heterotrophic organisms always there first? J Ecol 90: 569-577

> Hughes Martiny JB, Bohannan BJM, Brown JH, Colwell RK and others (2006) Microbial biogeography: putting microorganisms on the map. Nat Rev Microbiol 4:102-112

Jenkins B, Kitching RL, Pimm SL (1992) Productivity, disturbance and food web at a local spatial scale in experimental container habitats. Oikos 65:249-255

Kumar S, Nei M, Dudley J, Tamura K (2008) MEGA: a biologist-centric software for evolutionary analysis of DNA and protein sequences. Brief Bioinform 9:299-306

Lampert W, Sommer U (2007) Limnoecology: the ecology of lakes and streams. Oxford University Press, Oxford

Lewis LA, Lewis PO (2005) Unearthing the molecular phylodiversity of desert soil green algae (Chlorophyta). Syst Biol 54:936-947

Lopez-Bautista JM, Rindi F, Casamatta D (2007) The systematics of subaerial algae. In: Seckbach J (ed) Algae and cyanobacteria in extreme environments. Springer, Dordrecht, p 600-617

MacArthur RH, Wilson EO (1963) An equilibrium theory of insular zoogeography. Evolution 17:373-387

MacArthur RH, Wilson EO (1967) The theory of island biogeography. Princeton University Press, Princeton, NJ

Maguire B Jr (1963) The passive dispersal of small aquatic organisms and their colonization of isolated bodies of water. Ecol Monogr 33:161-185

> Marshall WA, Chalmers MO (1997) Airborne dispersal of Antarctic terrestrial algae and cyanobacteria. Ecography 20:585-594

Medlin L, Elwood HJ, Stickel S, Sogin ML (1988) The characterization of enzymatically amplified eukaryotic 16S-like rRNA-coding regions. Gene 71:491-499

Mihalatou HM, Moustaka-Gouni M (2002) Pico-, nano-, microplankton abundance and primary productivity in a eutrophic coastal area of the Aegean Sea, Mediterranean. Int Rev Hydrobiol 87:439-456
Munawar M, Weisse T (1989) Is the 'microbial loop' an early warning indicator of anthropogenic stress? In: Munawar M, Dixon G, Mayfield CI, Reynoldson T, Sadar MH (eds) Environmental bioassay techniques and their applications. Hydrobiologia 188/189:163-174

Polis GA, Anderson WB, Holt RD (1997) Toward an integration of landscape and food web ecology: the dynamics of spatially subsidized food webs. Annu Rev Ecol Syst 28: 289-316

Pratt JR, Cairns J Jr, Meier K (1985) Migration of species during early colonization. Am Midl Nat 113:92-101

Proctor VW (1957) Some controlling factors in the distribution of Haematococcus pluvialis. Ecology 38:457-462

> Rivera F, Lugo A, Ramirez E, Bonilla P and others (1992) Seasonal distribution of air-borne protozoa in Mexico City and its suburbs. Water Air Soil Pollut 61:17-36

Rogerson A, Detwiler A (1999) Abundance of airborne heterotrophic protists in ground level air of South Dakota. Atmos Res 51:35-44

> Roy-Ocotla G, Carrera J (1993) Aeroalgae: responses to some aerobiological questions. Grana 32:48-56

Schlichting HE Jr (1964) Meteorological conditions affecting the dispersal of airborne algae and protozoa. Lloydia 27 : $64-78$

Schlichting HE Jr (1969) The importance of airborne algae and protozoa. J Air Pollut Cont Assoc 19:946-951

> Sharma NK, Singh S, Rai AK (2006) Diversity and seasonal variation of viable algal particles in the atmosphere of a subtropical city in India. Environ Res 102:252-259

- Sharma NK, Rai AK, Singh S, Brown RM Jr (2007) Airborne algae: their present status and relevance. J Phycol 43: 615-627

Sherr EB, Sherr BF (1994) Bacterivory and herbivory: key roles of phagotrophic protists in pelagic food webs. Microb Ecol 28:223-235

Smith PE (1973) Effects of some air pollutants and meteorological conditions on airborne algae and protozoa. J Air Pollut Cont Assoc 23:876-880

Spiegelman D, Whissell G, Greer CW (2005) A survey of the methods for the characterization of microbial consortia and communities. Can J Microbiol 51:355-386

Stetzenbach LD (2002) Introduction to aerobiology. In: Hurst CJ, Crawford RL, Knudsen GR, McInerney MJ, Stetzenbach LD (eds) Manual of environmental microbiology, 2nd edn. ASM Press, Washington, DC, p 801-813

Stoeck T, Hayward B, Taylor GT, Varela R, Epstein SS (2006) A multiple PCR-primer approach to access the microeukaryotic diversity in environmental samples. Protist 157: $31-43$

Utermöhl H (1958) Zur Vervollkommnung der quantitativen Phytoplankton-Methodik. Mitt Int Ver Theor Angew Limnol 9:1-38

Voutsa D, Samara C, Kouimtzis Th, Ochsenkühn K (2002) Elemental composition of airborne particulate matter in the multi-impacted urban area of Thessaloniki, Greece. Atmos Environ 36:4453-4462

Weisse T (2002) The significance of inter- and intraspecific variation in bacterivorous and herbivorous protists. Antonie van Leeuwenhoek 81:327-341

Williams DD, Tavares-Cromar A, Coleman JR, Kushner DJ, Happey-Wood CM (1994) Colonization dynamics of algae in small artificial ponds. Can J Bot 72:1654-1665

Wintzingerode FV, Göbel UB, Stackebrandt E (1997) Determination of microbial diversity in environmental samples: pitfalls of PCR-based rRNA analysis. FEMS Microbiol Rev 21:213-229

Submitted: June 8, 2010; Accepted: September 30, 2010

Proofs received from author(s): December 13, 2010
Editorial responsibility: Urania Christaki, Wimereux, France 